\title{
Selenium-dependent Growth and Glycine Fermentation by Clostridium purinolyticum
}

\author{
By PETER DÜRRE† AND JAN R. ANDREESEN* \\ Institut für Mikrobiologie der Universität, Grisebachstrasse 8, D-3400 Göttingen, \\ Federal Republic of Germany
}

(Received 29 September 1981; revised 21 December 1981)

Clostridium purinolyticum fermented glycine as a sole carbon and energy source according to the equation:

$$
4 \text { Glycine }+2 \mathrm{H}_{2} \mathrm{O} \longrightarrow 3 \text { Acetate }+2 \mathrm{CO}_{2}+4 \mathrm{NH}_{3}
$$

The organism required adenine as a supplement and selenium compounds as micronutrients for growth. The molar growth yield on glycine was $6.5 \mathrm{~g}$ dry wt. Radiochemical and enzymic investigations revealed a new fermentation pathway for glycine in which 1 mol glycine was completely oxidized to $\mathrm{CO}_{2}$ and the generated reducing equivalents were used to reduce a further $3 \mathrm{~mol}$ glycine to acetate via the glycine reductase system. This reaction was associated with the formation of ATP.

\section{INTRODUCTION}

The ability to use glycine as a sole carbon and energy source under strictly anaerobic conditions is restricted to just a few bacterial species. Cardon \& Barker (1946) isolated Peptococcus (Diplococcus) glycinophilus, an organism which ferments glycine to acetate, carbon dioxide and ammonia; in addition, variable amounts of hydrogen gas are released. Strains of Peptococcus (Micrococcus) anaerobius and Peptococcus (Micrococcus) variabilis grow on glycine without the formation of hydrogen (Douglas, 1951). Guillaume et al. (1956) reported that Clostridium histolyticum decomposes glycine according to the same fermentation balance as that found for P. glycinophilus. To our knowledge there have been no further reports concerning the anaerobic degradation of glycine as a sole substrate by pure cultures, although there have been two reports concerning the fermentation of this amino acid by washed suspensions of rumen bacteria (Van den Hende et al., 1963; Wright \& Hungate, 1967); in both cases glycine was decomposed mainly to acetate. In Clostridium sticklandii and Clostridium sporogenes glycine serves only as electron acceptor in the Stickland reaction (Stadtman, 1978; Costilow, 1977).

The pathway of glycine fermentation in P. glycinophilus was elucidated by means of tracer experiments and enzymic investigations (Barker et al., 1948; Sagers \& Gunsalus, 1961; Klein \& Sagers, 1962). This bacterium grows only with glycine or several glycine-containing peptides (Cardon \& Barker, 1947). Clostridium purinolyticum possesses a similar narrow substrate spectrum in decomposing only purines and some degradation products, e.g. glycine (Dürre et al., 1981). The results reported in this paper show that $C$. purinolyticum ferments glycine by a mechanism different from that reported for $P$. glycinophilus. The proposed new pathway is energetically more favourable and includes glycine reductase and glycine decarboxylase as key enzymes.

† Present address: Department of Biochemistry, University of California, Berkeley, California 94720, U.S.A. 


\section{METHODS}

Organisms. Clostridium purinolyticum WA-1 (DSM 1384) was used throughout this study. Clostridium sticklandii (ATCC 12662; DSM 519) served as a control organism during the determination of glycine reductase activity and was kindly provided by Dr A. C. Schwartz, Institute of Botany, University of Bonn, F.R.G.

Growth media. Clostridium purinolyticum was grown in a medium containing $100 \mathrm{~mm}-\mathrm{glycine}, 4 \mathrm{mM}-\mathrm{K}_{2} \mathrm{HPO}_{4}$, $0.14 \mathrm{~mm}-\mathrm{MgSO}_{4}, 6.3 \mu \mathrm{M}-\mathrm{FeSO}_{4}, 29 \mu \mathrm{M}-\mathrm{CaCl}_{2}, 0.1 \mu \mathrm{M}-\mathrm{MnSO}_{4}, 0.1 \mu \mathrm{M}-\mathrm{Na}_{2} \mathrm{SeO}_{3}, 0.1 \mu \mathrm{M}-\mathrm{Na}_{2} \mathrm{WO}_{4}, 0.1 \mu \mathrm{M}-$ $\mathrm{Na}_{2} \mathrm{MoO}_{4}, 20 \mathrm{mM}-\mathrm{KHCO}_{3}, 2.3 \mathrm{~mm}-\left(\mathrm{NH}_{4}\right)_{2} \mathrm{SO}_{4}, 1.0 \mathrm{~mm}$-adenine, $29.2 \mathrm{~mm}$-thioglycollic acid and $0.1 \%(\mathrm{w} / \mathrm{v})$ yeast extract (Difco). Clostridium sticklandii was grown in the medium described by Stadtman (1978). All media were prepared anaerobically (under an atmosphere of $100 \% \mathrm{~N}_{2}$ ) by techniques described by Hungate (1969) and Bryant (1972). Traces of oxygen were removed from the gas stream by passage over a copper catalyst column heated to about $300^{\circ} \mathrm{C}$. Culture tubes $(16 \mathrm{ml})$ were from Bellco Glass, Vineland, N.J., U.S.A., and butyl rubber stoppers from Arthur H. Thomas Co., Philadelphia, Pa., U.S.A. Cells for enzyme determinations and tracer experiments were grown in 23 litre carboys containing 20 litre medium. Anaerobic conditions were established by gassing with $\mathrm{N}_{2}$ for $1 \mathrm{~h}$ before inoculation. In these cases sodium dithionite $\left(35 \mathrm{mg} \mathrm{l}^{-1}\right)$ was used as a reducing agent instead of thioglycollic acid.

Growth parameter measurements. The protein content of whole cells was determined according to Stickland (1951), and protein concentrations in cell-free extracts were measured by the method of Beisenherz et al. (1953). The dry weights of cells were determined on membrane filters and growth yields were calculated as described by Bauchop \& Elsden (1960) and Stouthamer (1969). Turbidity was measured at $600 \mathrm{~nm}$ using a Bausch \& Lomb Spectronic 88 or a Carl Zeiss PM 4 spectrophotometer.

Analytical methods. Acetate was determined by an enzymic procedure (Dorn et al., 1978), formate by the colorimetric method of Lang \& Lang (1972), glycine according to Sardesai \& Provido (1970), and ammonia as described by Da Fonseca-Wollheim et al. (1974). Carbon dioxide and hydrogen were measured with a Perkin-Elmer $\mathrm{F} 20 \mathrm{H}$ gas chromatograph [oven temperatures, $185^{\circ} \mathrm{C}$ and $100^{\circ} \mathrm{C}$, respectively; injection port temperatures, $185^{\circ} \mathrm{C}$ and $100^{\circ} \mathrm{C}$, respectively; thermal conductivity detector temperature, $230^{\circ} \mathrm{C}$; stainless steel columns $5.2 \mathrm{~mm} \times 200 \mathrm{~cm}$, filled with molecular sieve $5 \AA, 18-50$ mesh (E. Merck, Darmstadt, F.R.G.); carrier

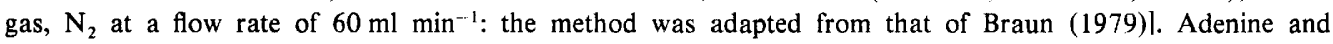
hypoxanthine were separated by high-pressure liquid chromatography (Du Pont model 870) on a reversed-phase column $(4.6 \mathrm{~mm} \times 250 \mathrm{~mm}$, packed with LiChrosorb RP-18, $10 \mu \mathrm{m})$. The purines were eluted with 100

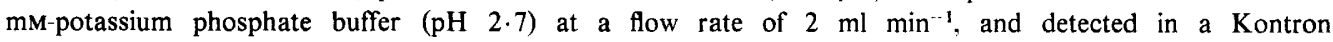
spectrophotometer (model $720 \mathrm{LC}$ ) at $205 \mathrm{~nm}$.

Tracer experiments. Radioactive glycine, or glycine in the presence of radioactive sodium acetate or sodium bicarbonate, was fermented by resting cells of $C$. purinolyticum in $120 \mathrm{ml}$ Warburg vessels. Washed cell suspension ( $5 \mathrm{ml} ; A_{600}$ about 50 ) was pipetted into the main compartment which contained, in addition, $24.5 \mathrm{ml}$ reaction buffer (composition similar to that of growth medium without glycine, adenine, $\mathrm{KHCO}_{3}$ and yeast extract, but supplemented with $0.15 \mu \mathrm{M}$-thiamin). The centre well contained $3 \mathrm{ml} \mathrm{KOH}(10 \%, \mathrm{w} / \mathrm{v})$ and a small piece of filter paper. Glycine solution $\left(0.5 \mathrm{ml}, 180 \mathrm{mg} \mathrm{ml}^{-1}\right)$ was placed in the side-arm and supplemented with the radioactive component. The Warburg flasks were then closed with serum stoppers and attached to a reciprocal shaker in a water bath at $37^{\circ} \mathrm{C}$. They were gassed with $\mathrm{N}_{2}$ for $1 \mathrm{~h}$ and the reaction was started by tipping the glycine solution from the side-arm into the main compartment. After 5-7 h the reaction was stopped by injecting $4 \mathrm{ml}$ of $4 \mathrm{M}-\mathrm{HCl}$. Subsequently, the flasks were shaken for $1 \mathrm{~h}$ to allow quantitative absorption of the $\mathrm{CO}_{2}$ formed by the $\mathrm{KOH}$. The reaction solution was centrifuged and acetate was separated from the other components by steam distillation. The purified acetate was degraded to $\mathrm{CO}_{2}$ and methylamine according to Sakami (1955). The radioactivity of the methylamine ( $\mathrm{in}_{2} \mathrm{SO}_{4} ; 10 \%$, w/v) and the $\mathrm{CO}_{2}$ (absorbed in $\mathrm{KOH} ; 10 \%$, w/v) was measured in a liquid scintillation counter (Philips; model PW4540). The scintillation mixture contained $5 \mathrm{ml}$ Unisolve I (Koch-Light), $0.5 \mathrm{ml}$ water and $0.1 \mathrm{ml}$ sample.

Enzyme assays. Cells were always harvested at the end of the exponential growth phase and stored anaerobically at $-20^{\circ} \mathrm{C}$. They were ruptured by French press treatment, and cell-free extracts were prepared as described by Leonhardt \& Andreesen (1977). All tests were performed under strictly anaerobic conditions. Formate dehydrogenase (EC 1.2.1.-) was assayed according to Dürre et al. (1981), methenyltetrahydrofolate cyclohydrolase (EC 3.5.4.9) by the methods of Uyeda \& Rabinowitz (1967a) and O'Brien \& Ljungdahl (1972), methylenetetrahydrofolate dehydrogenase (EC 1.5.1.5) according to Uyeda \& Rabinowitz (1967b) and O'Brien \& Ljungdahl (1972), formyltetrahydrofolate synthetase (EC 6.3.4.3) as described by Rabinowitz \& Pricer (1962) and O'Brien \& Ljungdahl (1972), glycine formiminotransferase (EC 2.1.2.4) by the method of Uyeda \& Rabinowitz (1965), serine hydroxymethyltransferase (EC 2.1.2.1) according to Barnard \& Akhtar (1979), glycine decarboxylase (EC 2.1.2.10) as described by Sagers \& Klein (1970) and glycine reductase using the radioactive test of Stadtman (1970). A second assay for glycine reductase was based on ATP formation during the reaction. It was carried out in $1 \mathrm{ml}$ cuvettes (path length $1 \mathrm{~cm}$ ) containing, in a total volume of $1 \mathrm{ml}$ : $10 \mathrm{~mm}-N$-tris(hydroxymethyl)methylglycine/KOH buffer (pH 8.25), $10 \mathrm{~mm}-\mathrm{MgCl}_{2}, 20 \mathrm{mM}-\mathrm{K}_{2} \mathrm{HPO}_{4}, 4 \mathrm{mM}-\mathrm{ADP}$, 
1 mM-NADP, 4 mm-AMP, $40 \mathrm{~mm}$-glycine, $20 \mathrm{~mm}$-dithiothreitol, $10 \mathrm{~mm}$-glucose, $42 \mathrm{U}$ hexokinase, $7 \mathrm{U}$ glucose-6-phosphate dehydrogenase, and extract. The reaction was started by adding either extract or glycine and the formation of NADPH was monitored at $340 \mathrm{~nm}$. L-Serine dehydratase (EC 4.2.1.13) activity was determined in $1 \mathrm{ml}$ cuvettes (path length $1 \mathrm{~cm}$ ) containing, in a total volume of $1 \mathrm{ml}: 100 \mathrm{~mm}$-potassium phosphate buffer (pH 8.4), $100 \mathrm{~mm}$-L-serine, $1 \mathrm{~mm}$-FeSO ${ }_{4}, 10 \mathrm{~mm}$-dithioerythritol, $55 \mathrm{U}$ L-lactate dehydrogenase, $0.3 \mathrm{~mm}-\mathrm{NADH}$, and extract. The reaction was started by adding activated extract, obtained by incubating cell-free extracts with $\mathrm{Fe}$ (II) and dithiothreitol as described by Carter \& Sagers (1972). The decrease in NADH was monitored at $366 \mathrm{~nm}$. One unit of enzyme activity was defined as $1 \mu \mathrm{mol}$ substrate transformed or product formed $\mathrm{min}^{-1}$ at $37^{\circ} \mathrm{C}$.

\section{RESULTS}

\section{Nutritional requirements}

The growth curve of Clostridium purinolyticum on glycine always showed a distinct deflexion in the early-exponential growth phase (Fig. 1) unless the medium was supplemented with adenine (Fig. 2). Synthetic amino acid solution, vitamins, pyrimidines (uracil, cytosine and thymine), or biogenic amines such as spermine, agmatine, putrescine and cadaverine, in various concentrations could not substitute for adenine. Even guanine was not effective. Moreover, the growth rate decreased as soon as the adenine component of the yeast extract in the medium was exhausted. The requirement of $C$. purinolyticum for adenine could be satisfied using a $1 \mathrm{~mm}$ concentration (Fig. 2). The glycine concentration which gave the best growth yield was $100 \mathrm{~mm}$. The organism showed no strict requirement for bicarbonate but in the presence of $0.2 \%(\mathrm{w} / \mathrm{v}) \mathrm{KHCO}_{3}$ the final turbidity of the culture was about $30 \%$ higher than in the unsupplemented culture. Higher concentrations proved to be somewhat inhibitory. Growth of $C$. purinolyticum on glycine was strictly dependent on the addition of the trace element selenium to the medium (Fig. 3), as was previously observed for growth on adenine (Dürre et al., 1981). Neither molybdenum nor tungsten could substitute for selenium. However, the addition of molybdenum and/or tungsten to the selenium-containing medium resulted in a further increase in growth. Maximum turbidity was reached at a concentration of $1 \mu \mathrm{M}$-selenite (Fig. 4) when the cultures were previously starved of this substance by at least five transfers $(1 \%, \mathrm{v} / \mathrm{v}$, inoculum each) in trace element-free medium. Obviously $C$. purinolyticum had the capability to concentrate selenium compounds very efficiently. If the organism was pre-cultured for several transfers in a medium supplemented with $0.1 \mu \mathrm{M}$ selenite, the final turbidity reached was similar to that obtained with $1 \mu \mathrm{M}$-selenite. For this reason a concentration of $0.1 \mu \mathrm{M}$-selenite was routinely chosen for all media. At $0.1 \mu \mathrm{M}$, selenomethionine was as effective as selenite, whereas selenocystine gave a lower stimulation. Chemically related elements such as tellurium and sulphur (in the form of tellurite, sulphate and cysteine) did not exhibit any stimulatory effect on growth (Fig. 4). The curves for sulphate and cysteine were identical to that for tellurite and are therefore not shown.

\section{Substrate utilization and fermentation products}

The growth response of $C$. purinolyticum on glycine is shown in Fig. 2. Exponential growth occurred between 3 and $11 \mathrm{~h}$ after inoculation, as judged by the turbidity of the culture, its protein content and the dry weight of the cells. After reaching the stationary phase, cell lysis was observed. The protein : dry weight ratio of the cells was about $60-70 \%$ throughout the growth cycle, indicating that no storage material was formed. The doubling time was $3.7 \mathrm{~h}$ as calculated from the increase in turbidity. A maximum turbidity $\left(A_{600}\right)$ of 1.14 was measured, corresponding to a dry weight of $0.4 \mathrm{mg} \mathrm{ml}^{-1}$. The molar growth yield was $6.5 \mathrm{~g}$ dry wt (mol glycine $)^{-1}$. The fermentation products were acetate, $\mathrm{NH}_{3}$ and $\mathrm{CO}_{2}$. Formate and $\mathrm{H}_{2}$ could not be detected. Glycine became depleted when the cells reached the stationary phase. Adenine was rapidly broken down, being degraded to hypoxanthine which could be detected in the medium. Subsequently, the cells took up this purine, probably utilizing it in biosynthetic reactions. The total purine content of the medium was exhausted after $13 \mathrm{~h}$. The acetate level 


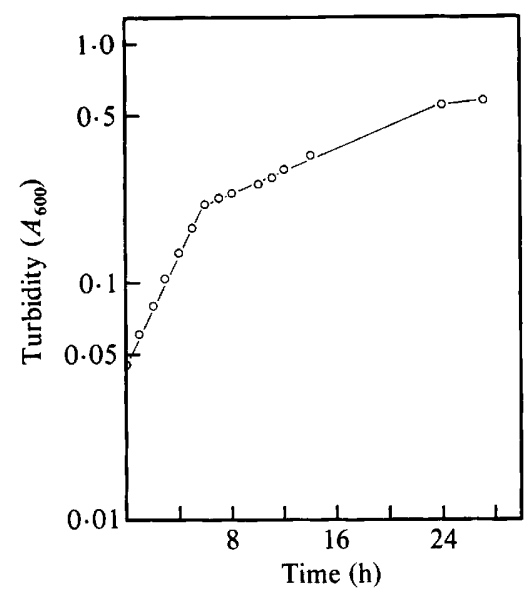

Fig. 1

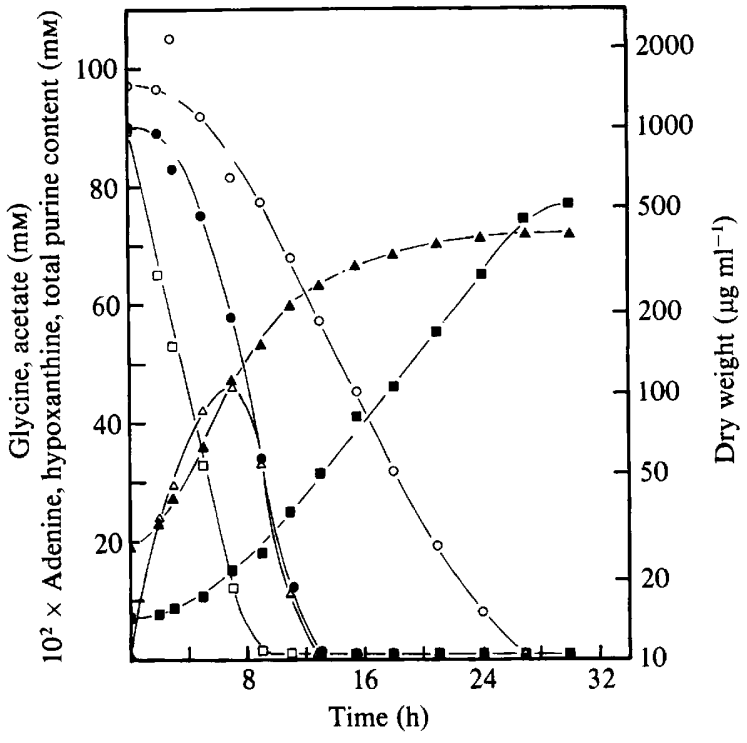

Fig. 2

Fig. 1. Growth curve of $C$. purinolyticum on glycine without addition of adenine to the medium. Turbidity was measured in anaerobic culture tubes with a Spectronic 88 spectrophotometer.

Fig. 2. Growth, substrate utilization and product formation by $C$, purinolyticum during growth on glycine. Cells were cultured in a $4 \mathrm{l}$ fermenter under strictly anaerobic conditions. The volume of the gas phase in this apparatus was kept constant by a special construction and the $\mathrm{pH}$ was kept constant at 7.5. $O$, glycine; $\square$, adenine; $\Delta$, hypoxanthine; $\mathbf{O}$, total purine content of the medium; $\boldsymbol{\square}$, acetate; $\boldsymbol{\Delta}$, dry weight.

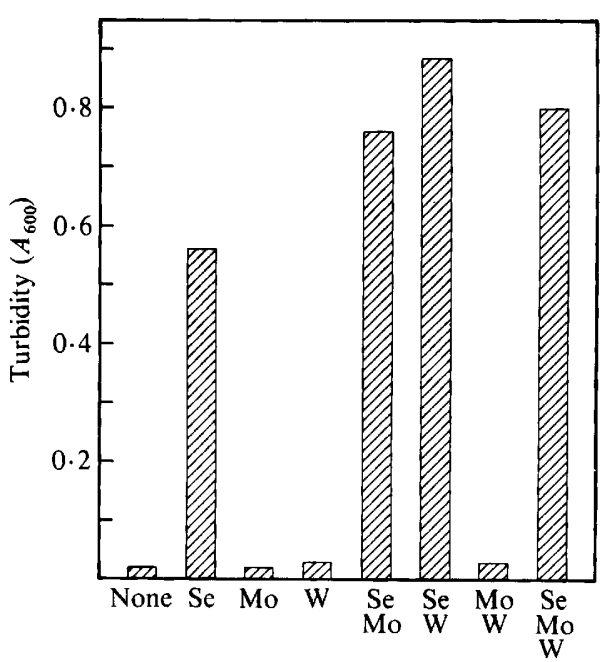

Trace element(s) added

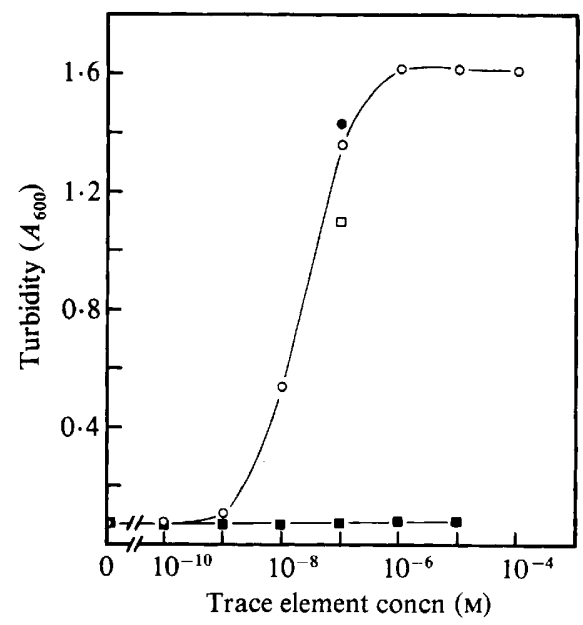

Fig. 4

Fig. 3

Fig. 3. Influence of trace elements on growth of $C$. purinolyticum on glycine. The medium used was
that described in Methods with the omission of $\mathrm{SeO}_{3}^{2-}, \mathrm{WO}_{4}^{2-}$, and $\mathrm{MoO}_{4}^{2-}$. Data shown give the that described in Methods with the omission of $\mathrm{SeO}_{3}^{2-}, \mathrm{WO}_{4}^{2-}$, and $\mathrm{MoO}_{4}^{2-}$. Data shown give the maximum turbidities reached after supplementation of the medium with various combinations of these elements $\left(10^{-7} \mathrm{M}\right)$ and inoculation with starved cells.

Fig. 4. Influence of increasing concentrations of selenium and tellurium compounds on growth of $C$. purinolyticum on glycine. The conditions were the same as described in Fig. 3. $\mathrm{O}$, selenite; selenomethionine; $\square$, selenocystine; $\mathbf{\square}$, tellurite. 
Table 1. Fermentation balance for glycine decomposition by C. purinolyticum

Resting cells were incubated with glycine in a Warburg vessel at $37^{\circ} \mathrm{C}$. For culture conditions and metabolite determinations, see Methods. Calculation of the oxidation-reduction $(O / R)$ balance was performed according to the method of Whiteley \& Douglas (1951) adapted to the definition of Wood (1961)

\begin{tabular}{|c|c|c|c|c|c|c|}
\hline \multirow[b]{2}{*}{$\begin{array}{l}\text { Substrate and } \\
\text { products }\end{array}$} & \multirow[b]{2}{*}{$\begin{array}{c}\text { mmol } \\
(100 \mathrm{mmol} \text { substrate })^{-1}\end{array}$} & \multirow[b]{2}{*}{$\begin{array}{c}\mathrm{mmol} \mathrm{C} \\
(100 \mathrm{mmol})^{-1}\end{array}$} & \multicolumn{2}{|c|}{$\mathrm{O} / \mathrm{R}$ balance } & \multicolumn{2}{|c|}{ Balance of available $\mathrm{H}$} \\
\hline & & & $\begin{array}{l}\mathrm{O} / \mathrm{R} \\
\text { value }\end{array}$ & $\begin{array}{c}\mathrm{mmol} \\
(100 \mathrm{mmol})^{-1}\end{array}$ & $\begin{array}{c}\text { available } \\
\mathrm{H}\end{array}$ & $\begin{array}{c}\mathrm{mmol} \\
(100 \mathrm{mmol})^{-}\end{array}$ \\
\hline Glycine & $100 \cdot 0$ & $200 \cdot 0$ & +1 & +100 & 6 & $600 \cdot 0$ \\
\hline Acetate & 72.7 & $145 \cdot 4$ & 0 & 0 & 8 & $581 \cdot 6$ \\
\hline Ammonia & 97.0 & 0 & 0 & 0 & 0 & 0 \\
\hline $\begin{array}{l}\mathrm{CO}_{2} \\
\quad \text { Balance }\end{array}$ & $47 \cdot 5$ & $\frac{47.5}{96 \cdot 5 \%}$ & +2 & $\frac{+95}{1.05}$ & 0 & $\frac{0}{96.9 \%}$ \\
\hline
\end{tabular}

Table 2. Distribution of radioactivity in the products of glycine decomposition by resting cells of C. purinolyticum in the presence of ${ }^{14} \mathrm{C}$-labelled substances

Conditions were as described in Methods. Glycine was used at a concentration of $1.2 \mathrm{mmol}$ (per $30 \mathrm{ml})$ in each experiment; $\left[1-{ }^{14} \mathrm{C}\right]$ acetate, $\left[2-{ }^{14} \mathrm{C}\right]$ acetate and $\left[{ }^{14} \mathrm{C}\right.$ lbicarbonate were added at concentrations of $0.11 \mu \mathrm{mol}, 0.11 \mu \mathrm{mol}$ and $0.68 \mu \mathrm{mol}$, respectively. The ${ }^{14} \mathrm{C}$ balance was calculated according to the fermentation equation: 4 Glycine $+2 \mathrm{H}_{2} \mathrm{O} \rightarrow 3$ Acetate $+2 \mathrm{CO}_{2}+4 \mathrm{NH}_{3}$.

\begin{tabular}{|c|c|c|c|c|c|}
\hline & & cific radioactivit & (d.p.m. $\mathrm{mmol}^{-1}$ ) & & \\
\hline & & & Products & & \\
\hline Labelled substrate & Substrate & $\begin{array}{c}\mathrm{CH}_{3} \text { group of } \\
\text { acetate* }\end{array}$ & $\begin{array}{l}\mathrm{COOH} \text { group of } \\
\text { acetate* }\end{array}$ & $\mathrm{CO}_{2}$ & $\begin{array}{c}{ }^{14} \mathrm{C} \text { balance } \\
(\%)\end{array}$ \\
\hline$\left[1{ }^{-14} \mathrm{C}\right]$ Glycine & $3.7 \times 10^{5}$ & $41220(12 \cdot 3)$ & $292730(87 \cdot 7)$ & 201360 & 94.9 \\
\hline$\left[2-{ }^{14} \mathrm{C}\right]$ Glycine & $3.7 \times 10^{5}$ & $381760(94.4)$ & $22430(5.6)$ & 91690 & $94 \cdot 3$ \\
\hline$\left[1-^{-14} \mathrm{C}\right]$ Acetate & $4.0 \times 10^{9}$ & $14140(8 \cdot 5)$ & $153200(91 \cdot 5)$ & 91140 & $46 \cdot 2$ \\
\hline$\left[2-{ }^{14} \mathrm{C}\right]$ Acetate & $4.0 \times 10^{9}$ & $73660(91.6)$ & $6740(8.4)$ & 39790 & $21 \cdot 7$ \\
\hline $\mathrm{NaH}^{14} \mathrm{CO}_{3}$ & $6.5 \times 10^{8}$ & $5390(52 \cdot 2)$ & $4920(47 \cdot 7)$ & 600310 & $83 \cdot 2$ \\
\hline
\end{tabular}

* Numbers in parentheses indicate the percentage of acetate labelled in the group specified.

increased during the course of the glycine fermentation, lowering the $\mathrm{pH}$ to a final value of about 6.9. Production of $\mathrm{NH}_{3}$ and $\mathrm{CO}_{2}$ was determined in another experiment. A typical fermentation balance is given in Table 1 . These data are in accordance with the following fermentation equation:

$$
4 \text { Glycine }+2 \mathrm{H}_{2} \mathrm{O} \longrightarrow 3 \text { Acetate }+2 \mathrm{CO}_{2}+4 \mathrm{NH}_{3}
$$

As previously reported $C$. purinolyticum is also able to grow with formiminoglycine (Dürre $e t$ al., 1981). Fermentation experiments showed that this compound is decomposed according to the equation:

$$
1 \text { Formiminoglycine } \longrightarrow 0.88 \text { Acetate }+0.11 \text { Formate }+0.95 \mathrm{CO}_{2}
$$

$\left(\mathrm{NH}_{3}\right.$ was not determined).

\section{Tracer experiments}

Resting cells of $C$. purinolyticum were used to ferment $\left[1-{ }^{14} \mathrm{C}\right]$ glycine and $\left[2-{ }^{14} \mathrm{C}\right]$ glycine (Table 2). As a control, decomposition of glycine in the presence of radioactive $\left[1-{ }^{14} \mathrm{C}\right]$ acetate, $\left[2-{ }^{14} \mathrm{C}\right]$ acetate or $\left[{ }^{14} \mathrm{C}\right]$ bicarbonate was tested. Nearly all the radioactive glycine was directly fermented to the correspondingly labelled radioactive acetate. 'Missing' 
Table 3. Specific activities of enzymes of C. purinolyticum participating in glvcine metabolism

Culture conditions and assay systems were as described in Methods.

\begin{tabular}{lc}
\multicolumn{1}{c}{ Enzyme } & $\begin{array}{c}\text { Specific activity } \\
\text { [units (mg protein) }\end{array}$ \\
Glycine reductase (radiochemical test) & 0.090 \\
Glycine reductase (measured by ATP & 0.041 \\
formation) & 0.012 \\
Glycine decarboxylase & 1.1 \\
Methylenetetrahydrofolate dehydrogenase & 0.007 \\
(NADP as coenzyme) & 35.5 \\
Methenyltetrahydrofolate cyclohydrolase & 1.0 \\
Formyltetrahydrofolate synthetase & present \\
Formate dehydrogenase & 3.2 \\
Formiminotetrahydrofolate cyclodeaminase & 0.2 \\
Glycine formiminotransferase & 1.8 \\
Serine hydroxymethyltransferase & 0.06 \\
L-Serine dehydratase & \\
Glycine reductase $(C$. sticklandii: & \\
radiochemical test) &
\end{tabular}

radioactivity as calculated from the ${ }^{14} \mathrm{C}$ balance always appeared in the cells. Part of the substrate was completely oxidized to $\mathrm{CO}_{2}$. Most of the added acetate was either taken up by the cells or oxidized to $\mathrm{CO}_{2}$, since only $22-46 \%$ could be detected in the medium. The cells were able to convert $\mathrm{CO}_{2}$ to acetate as shown by the results of the experiment performed with radioactive bicarbonate. It can be seen that acetate is derived directly from glycine. The small deviations from the theoretical value corresponded to the exchange determined in the control experiments with radioactive acetate. Only a very small amount of added ${ }^{14} \mathrm{CO}_{2}$ was converted to acetate with both carbon atoms equally labelled.

\section{Enzyme studies}

Activities of enzymes known to be involved in glycine metabolism were shown to be present in cell-free extracts of $C$. purinolyticum (Table 3). A high glycine reductase activity was detected as expected from the results of the tracer experiments. This enzyme converts glycine directly to acetate, releasing ammonia. Dithiothreitol was used as the electron donor. Furthermore, glycine-dependent ATP production could be observed during this reaction. Cell-free extracts of $C$. sticklandii showed a somewhat lower activity of the enzyme although the value was about 10-fold higher than those reported by Stadtman \& Elliott (1956). This might be due to the more gentle storage conditions established by Barnard \& Akhtar (1979) and also used by us. The activities determined for glycine decarboxylase, formyltetrahydrofolate synthetase, methenyltetrahydrofolate cyclohydrolase and methylenetetrahydrofolate dehydrogenase were of about the same order as known for purine-fermenting clostridia (Champion \& Rabinowitz, 1977). Methylenetetrahydrofolate dehydrogenase reacted with both NAD and NADP as coenzymes but the activity measured with NADP was 3- to 10-fold higher than that with NAD. Uyeda \& Rabinowitz (1967b) obtained similar results with crude extracts of $C$. cylindrosporum whereas the pure enzyme was specific for NADP. The test system for the glycine formiminotransferase also allows the detection of formiminotetrahydrofolate cyclodeaminase activity (Uyeda \& Rabinowitz, 1965) which was also present in $C$. purinolyticum. Formate dehydrogenase, L-serine dehydratase, and serine hydroxymethyltransferase showed comparatively low activities. Preliminary results indicated the presence of a pyruvate : methylviologen oxidoreductase. 


\section{DISCUSSION}

Glycine seems to be a difficult substrate to utilize for growth. This might be due to its interference with cell wall biosynthesis (Schleifer et al., 1976). As already mentioned, besides C. purinolyticum, only two anaerobic bacteria are known to ferment this amino acid as sole carbon and energy source. The striking nutritional features of $C$. purinolyticum during growth on glycine are the requirements for adenine and selenium compounds. Omission of adenine from the medium did not prevent growth completely, indicating that the organism is able to synthesize purines de novo. The deflecting growth curve suggests that the rate of purine synthesis is limiting under these conditions. Since $C$. purinolyticum can use purines as a carbon and energy source (Dürre et al., 1981), degradation and synthesis of these compounds must be regulated very carefully. The thiamin requirement of most purine-utilizing anaerobes (J. R. Andreesen, P. Dürre, H. Schiefer \& R. Wagner, unpublished results) might be due to the restricted biosynthetic capacity in the common reactions of purine and thiamin formation (Newell \& Tucker, 1968). Clostridium purinolyticum may satisfy its requirement for purines by converting adenine first into hypoxanthine which is subsequently used for the production of purines needed for the synthesis of nucleic acids and coenzymes. The detection of hypoxanthine in the medium during growth may be an indication that the first reaction is performed by an exo-enzyme or a periplasmic enzyme resulting in an imbalance between the rates of production and utilization of hypoxanthine.

Only a few instances of a similar strict requirement for selenium compounds have been described. Both $C$. sticklandii and $C$. sporogenes need selenite for the utilization of glycine as an oxidant in the Stickland reaction (Turner \& Stadtman, 1973; Costilow, 1977). Selenite is an essential nutrient for Peridinium cinctum fa. westii (Lindström \& Rodhe, 1978). The last two organisms have therefore been suggested for use in a bioassay for selenium (Costilow, 1977; Lindström, 1980). During decomposition of purines, $C$. purinolyticum also shows a requirement for selenium which, however, can be partly satisfied by molybdate and tungstate (Dürre et al., 1981). The extremely low concentrations of selenite which proved to be effective for growth on glycine point to a high-affinity selenium transport system in this organism.

The dependence on the trace element selenium first gave rise to the idea that a glycine reductase might be involved in glycine fermentation, because selenium was shown to be an essential component of this enzyme complex (Turner \& Stadtman, 1973). The reaction catalysed by glycine reductase was discovered by Stadtman \& Elliott (1956) while investigating the degradation of glycine and other amino acids in a Stickland reaction by $C$. sticklandii. They reported that the direct reduction of glycine to acetate was concomitant with the formation of ATP from ADP plus inorganic phosphate. The results of the tracer experiments (Table 2) and the enzyme assays (Table 3) prove that in vivo the acetate formation from glycine in $C$. purinolyticum does involve such an enzyme. Furthermore, energy production during the reaction could be observed. Hence, the pathway of glycine fermentation operating in $C$. purinolyticum is different from that known for Peptococcus glycinophilus. The latter decarboxylates glycine to methylenetetrahydrofolate which is condensed with a second molecule of glycine, yielding serine. Serine is subsequently converted to pyruvate from which acetate is formed (Sagers \& Gunsalus, 1961; Klein \& Sagers, 1962). Only $1 \mathrm{~mol}$ ATP is synthesized during the degradation of $4 \mathrm{~mol}$ glycine. The fermentation follows the equation (Cardon \& Barker, 1946):

$$
4 \text { Glycine }+2 \mathrm{H}_{2} \mathrm{O} \longrightarrow 3 \text { Acetate }+2 \mathrm{CO}_{2}+4 \mathrm{NH}_{3}
$$

Although $C$. purinolyticum ferments glycine according to the same overall balance, the pathway proposed is completely different (Fig. 5). This scheme is in accordance with all the results from the tracer experiments and enzyme assays. $1 \mathrm{~mol}$ glycine is oxidized to $\mathrm{CO}_{2}$, thus providing energy via the formyltetrahydrofolate synthetase reaction. The enzyme of $C$. purinolyticum was not assayed by formate production; however, all other known enzymes catalyse ATP formation during this reaction (Himes \& Harmony, 1973) so that a similar 


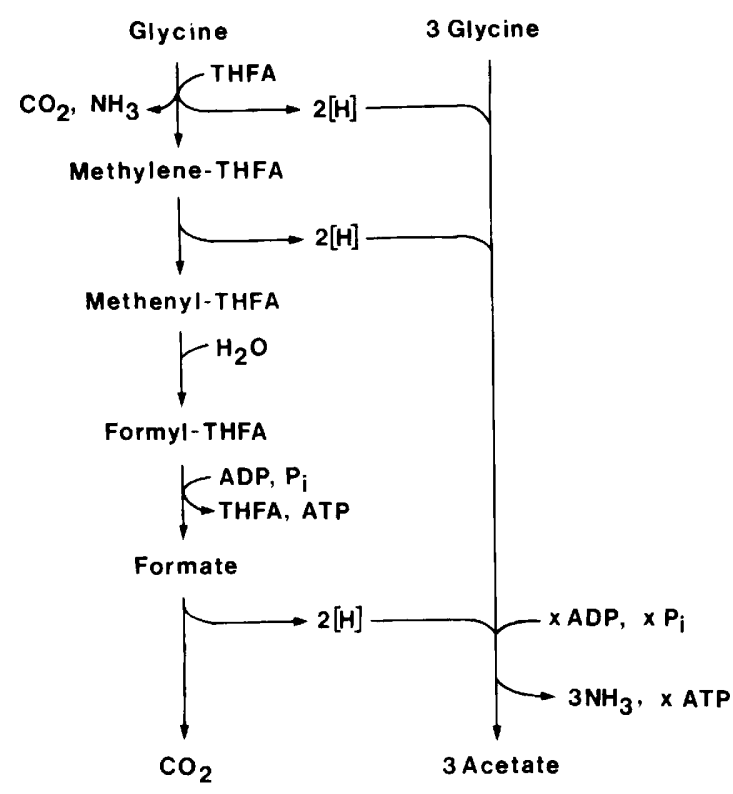

Fig. 5. Proposed pathway of glycine fermentation by $C$. purinolyticum. Abbreviations: THFA, tetrahydrofolic acid; $2[\mathrm{H}]$, reducing equivalents; $\mathrm{P}_{\mathrm{i}}$, inorganic phosphate.

process can be assumed to function in this organism. The reducing equivalents produced during the oxidation of $1 \mathrm{~mol}$ glycine are transferred to a glycine reductase which reduces $3 \mathrm{~mol}$ glycine to $3 \mathrm{~mol}$ acetate and $3 \mathrm{~mol}$ ammonia, concomitant with the formation of ATP. The stoichiometry of glycine reduction and ATP formation is not quite clear. In C. sticklandii a ratio of 1:1 was reported (Stadtman et al., 1957). However, Barnard \& Akhtar (1979) obtained a lower proportion which they attributed to the presence of active ATPase in the cell-free extracts. The determination of an exact stoichiometry can only be performed with lysates free of adenylate kinase (Tanaka \& Stadtman, 1979). These factors may be responsible for the lower glycine reductase activities obtained with the ATP assay (Table 3 ).

According to the proposed pathway, the molar growth yield of $6.5 \mathrm{~g}$ dry wt (mol glycine) $)^{-1}$ determined in $C$. purinolyticum will be equivalent to a $Y_{\mathrm{ATP}}$ of $6.5 \mathrm{~g}$ dry wt (mol ATP) ${ }^{-1}$ because a maximum of 4 mol ATP can be gained from 4 mol glycine ( 1 mol during the formyltetrahydrofolate synthetase reaction and 3 mol during the glycine reductase reaction). Although $Y_{\text {ATP }}$ was originally thought to be a biological constant, many studies have indicated that it may vary in the range $4 \cdot 7-28.5$ in anaerobic bacteria, depending on, for example, the size of the carbon skeleton of the substrate (Stouthamer, 1979). From this point of view it is probable that $C$. purinolyticum forms ATP via the reductase system as indicated by the enzymic studies. Thermodynamic data show that a free energy change $\left(\Delta G^{\circ}\right)$ of $-207.5 \mathrm{~kJ}(4 \mathrm{~mol} \text { glycine })^{-1}$ [i.e. $-49.6 \mathrm{kcal}(4 \mathrm{~mol} \text { glycine })^{-1}$ ] can be calculated for the reaction:

$$
4 \text { Glycine }+4 \mathrm{H}_{2} \mathrm{O} \rightarrow 3 \text { Acetate }^{-}+2 \mathrm{HCO}_{3}^{-}+4 \mathrm{NH}_{4}^{+}+\mathrm{H}^{+}
$$

(all data taken from Thauer et al., 1977). This corresponds to a value of $-51.9 \mathrm{~kJ}$ (mol glycine transformed) ${ }^{-1}$ (i.e. $-12.4 \mathrm{kcal} \mathrm{mol}^{-1}$ ). Because the formation of $1 \mathrm{~mol}$ ATP must be associated with a free energy change of -41.8 to $-50.2 \mathrm{~kJ} \mathrm{~mol}^{-1}$ (i.e. -10 to $-12 \mathrm{kcal}$ $\mathrm{mol}^{-1}$ ), the formation of $4 \mathrm{~mol}$ ATP during the reaction described above would result in a thermodynamic efficiency of more than $80 \%$. Up to now, only values up to $70 \%$ are known (McCarty, 1964). Further investigation is necessary to clarify the stoichiometry of glycine 
reduction and ATP formation in $C$. purinolyticum. It would be helpful to investigate the fermentation of formiminoglycine in detail, because the formimino group of this compound is obviously oxidized to formate and $\mathrm{CO}_{2}$ via tetrahydrofolate derivatives, whereas the remaining glycine is reduced to acetate. This scheme implies a $1: 1$ ratio between the two reaction sequences, which would allow a more precise determination of the amount of energy gained. The glycine-serine pathway is probably only used for biosynthetic purposes, as indicated by the tracer experiments and the low activities of both serine hydroxymethyltransferase and L-serine dehydratase. In Clostridium acidiurici, an organism known to generate energy via this pathway, the activities are 400 and 8 times higher, respectively (Carter \& Sagers, 1972; Champion \& Rabinowitz, 1977).

Fermentation of glycine as sole carbon and energy source via a glycine reductase was presumed to occur in rumen bacteria (Van den Hende et al., 1963). The authors based this conclusion only on the fact that no $\mathrm{CO}_{2}$ was released during the decomposition of glycine. In contrast, Wright \& Hungate (1967) assumed that suspensions of rumen micro-organisms fermented glycine mainly in the same manner as $P$. glycinophilus, although the data from their tracer experiments pointed to a high participation of a glycine reductase $(82.8 \%$ conversion of $\left[1{ }^{14} \mathrm{C}\right]$ glycine into $\left[1-{ }^{14} \mathrm{C}\right]$ acetate; $56.5 \%$ conversion of $\left[2-{ }^{14} \mathrm{C}\right]$ glycine into $\left[2-{ }^{14} \mathrm{C}\right]$ acetate). The results expected from the glycine-serine system would be $0 \%$ and $25 \%$, respectively. It therefore seems possible that glycine degradation via a glycine reductase is more widespread than previously thought.

This work was supported by a grant from the Deutsche Forschungsgemeinschaft.

\section{REFERENCES}

Barker, H. A., Volcani, B. E. \& Cardon, B. P. (1948). Tracer experiments on the mechanism of glycine fermentation by Diplococcus glycinophilus. Journal of Biological Chemistry 173, 803-804.

BARNARD, G. F. \& AKhtaR, M. (1979). Mechanistic and stereochemical studies on the glycine reductase of Clostridium sticklandii. European Journal of Biochemistry 99, 593-603.

BAUChOP, T. \& ElsDEN, S. R. (1960). The growth of micro-organisms in relation to their energy supply. Journal of General Microbiology 23, 457-469.

Beisenherz, G., Boltze, H. J., BÜCher, T., CzoK, R., Garbade, K. H., MEYer-ARENDT, E. \& Pfleiderer, G. (1953). DiphosphofructoseAldolase, Phosphoglyceraldehyd-Dehydrogenase, Milchsäure-Dehydrogenase, GlycerophosphatDehydrogenase und Pyruvat-Kinase aus Kaninchenmuskulatur in einem Arbeitsgang. Zeitschrift für Naturforschung 8b, 555-577.

BRAUN, K. (1979). Untersuchungen zum autotrophen, heterotrophen und mixotrophen Wachstum von Acetobacterium woodii und Clostridium aceticum. Ph.D. thesis, University of Göttingen, F.R.G.

Bryant, M. P. (1972). Commentary on the Hungate technique for culture of anaerobic bacteria. American Journal of Clinical Nutrition 25, 13241328.

Cardon, B. P. \& Barker, H. A. (1946). Two new amino-acid-fermenting bacteria, Clostridium propionicum and Diplococcus glycinophilus. Journal of Bacteriology 52, 629-634.

CARdon, B. P. \& BARKer, H. A. (1947). Amino acid fermentations by Clostridium propionicum and Diplococcus glycinophilus. Archives of Biochemistry 12, 165-180.
Carter, J. E. \& SAgers, R. D. (1972). Ferrous ion-dependent L-serine dehydratase from Clostridium acidiurici. Journal of Bacteriology 109, 757-763.

Champion, A. B. \& Rabinowitz, J. C. (1977). Ferredoxin and formyltetrahydrofolate synthetase: comparative studies with Clostridium acidiurici, Clostridium cylindrosporum, and newly isolated anaerobic uric acid-fermenting strains. Journal of Bacteriology 132, 1003-1020.

CostiLow, R. N. (1977). Selenium requirement for the growth of Clostridium sporogenes with glycine as the oxidant in Stickland reaction systems. Journal of Bacteriology 131, 366-368.

Da Fonseca-Wollheim, F., Bergmeyer, H. U. \& GutmanN, I. (1974). Ammoniak. In Methoden der enzymatischen Analyse, 3rd edn, pp. 1850-1853. Edited by H. U. Bergmeyer. Weinheim: Verlag Chemie.

Dorn, M., Andreesen, J. R. \& Gottschalk, G. (1978). Fermentation of fumarate and L-malate by Clostridium formicoaceticum. Journal of Bacteriology 133, 26-32.

Douglas, H. C. (1951). Glycine fermentation by nongas forming anaerobic micrococci. Journal of Bacteriology 62, 517-518.

Dürre, P., ANDERSCH, W. \& ANDREesen, J. R. (1981). Isolation and characterization of an adenineutilizing, anaerobic sporeformer, Clostridium purinolyticum sp.nov. International Journal of Systematic Bacteriology 31, 184-194.

Guillaume, J., Beerens, H. \& Osteux, H. (1956). Production de gaz carbonique et fermentation du glycocolle par Clostridium histolyticum. Annales de l'Institut Pasteur 91, 721-726. 
Himes, R. H. \& Harmony, J. A. K. (1973). Formyltetrahydrofolate synthetase. CRC Critical Reviews in Biochemistry 1, 501-535.

HuNGATE, R. E. (1969). A roll tube method for cultivation of strict anaerobes. Methods in Microbiology 3B, 117-132.

KLEIN, S. M. \& SAGERS, R. D. (1962). Intermediary metabolism of Diplococcus glycinophilus. II. Enzymes of the acetate-generating system. Journal of Bacteriology 83, 121-126.

LANG, E. \& LANG, H. (1972). Spezifische Farbreaktion zum direkten Nachweis der Ameisensäure. Zeitschrift für analytische Chemie 260, 8-10.

LeonhardT, U. \& ANDREESEN, J. R. (1977). Some properties of formate dehydrogenase, accumulation and incorporation of ${ }^{185} \mathrm{~W}$-tungsten into proteins of Clostridium formicoaceticum. Archives of Microbiology 115, 277-284.

LINDSTRöM, K. (1980). Peridinium cinctum bioassays of Se in Lake Erken. Archiv für Hydrobiologie 89, 110-117.

LindSTRÖM, K. \& RodHE, W. (1978). Selenium as a micronutrient for the dinoflagellate Peridinium cinctum fa westii. Mitteilungen der Internationalen Vereinigung für theoretische und angewandte Limnologie 21, 168-173.

MCCarty, P. L. (1964). Thermodynamics of biological synthesis and growth. Advances in Water and Pollution Research 2, 169-199.

Newell, P. C. \& TuCkeR, R. G. (1968). Biosynthesis of the pyrimidine moiety of thiamine. A new route of pyrimidine biosynthesis involving purine intermediates. Biochemical Journal 106, 279-287.

O'Brien, W. E. \& LJUNGDAHL, L. G. (1972). Fermentation of fructose and synthesis of acetate from carbon dioxide by Clostridium formicoaceticum. Journal of Bacteriology 109, 626-632.

Rabinowitz, J. C. \& Pricer, W. E., JR (1962). Formyltetrahydrofolate synthetase. I. Isolation and crystallization of the enzyme. Journal of Biological Chemistry 237, 2898-2902.

Sagers, R. D. \& Gunsalus, I. C. (1961). Intermediary metabolism of Diplococcus glycinophilus. I. Glycine cleavage and one-carbon interconversions. Journal of Bacteriology 81, 541-549.

SAGERS, R. D. \& KLeIN, S. M. (1970). Bicarbonateglycine exchange (Peptococcus glycinophilus). Methods in Enzymology 17A, 970-976.

SAKAmI, W. (1955). Handbook of Isotope Tracer Methods. Cleveland: Case Western Reserve University.

Sardesai, V. M. \& Provido, H. S. (1970). The determination of glycine in biological fluids. Clinica chimica acta 29, 67-71.

Schleifer, K. H., Hammes, W. P. \& Kandler, O. (1976). Effect of endogenous and exogenous factors on the primary structures of bacterial peptidoglycan. Advances in Microbial Physiology 13, 245-292.

Stadtman, T. C. (1970). Glycine reductase system (Clostridium). Methods in Enzymology 17A, 959966.

Stadtman, T. C. (1978). Selenium-dependent clostri- dial glycine reductase. Methods in Enzymology 53, 372-382.

Stadtman, T. C. \& Elliott, P. (1956). A new ATP-forming reaction: the reductive deamination of glycine. Journal of the American Chemical Society 78, 2020-2021.

Stadtman, T. C., Elliott, P. \& Tiemann, L. (1957). Studies on the enzymic reduction of amino acids. III. Phosphate esterification coupled with glycine reduction. Journal of Biological Chemistry 231, 961-973.

STICKLAND, L. H. (1951). The determination of small quantities of bacteria by means of the biuret reaction. Journal of General Microbiology 5, 698703.

Stouthamer, A. H. (1969). Determination and significance of molar growth yields. Methods in Microbiology 1, 629-663.

Stouthamer, A. H. (1979). The search for correlation between theoretical and experimental growth yields. In Microbial Biochemistry, International Review of Biochemistry, vol. 21, pp. 1-47. Edited by J. R. Quayle. Baltimore: University Park Press.

Tanaka, H. \& Stadtman, T. C. (1979). Selenium dependent clostridial glycine reductase. Purification and characterization of the two membraneassociated protein components. Journal of Biological Chemistry 254, 447-452.

Thauer, R. K., Jungermann, K. \& Decker, K. (1977). Energy conservation in chemotrophic anaerobic bacteria. Bacteriological Reviews 41, 100-180.

Turner, D. C. \& Stadtman, T. C. (1973). Purification of protein components of the clostridial glycine reductase system and characterization of protein $\mathrm{A}$ as a selenoprotein. Archives of Biochemistry and Biophysics 154, 366-381.

UyedA, K. \& RABINOwITZ, J. C. (1965). Metabolism of formiminoglycine. Glycine formiminotransferase. Journal of Biological Chemistry 240, 1701-1710.

UYEDA, K. \& RABINOwITZ, J. C. (1967a). Metabolism of formiminoglycine. Formiminotetrahydrofolate cyclodeaminase. Journal of Biological Chemistry 242, 24-31.

UYEDA, K. \& RABINOWITZ, J. C. (1967b). Enzymes of clostridial purine fermentation. Methylenetetrahydrofolate dehydrogenase. Journal of Biological Chemistry 242, 4378-4385.

VAN DEN Hende, C., Oyaert, W. \& Bouchaert, J. H. (1963). Metabolism of glycine, alanine, valine, leucine and isoleucine by rumen bacteria. Research in Veterinary Science 4, 382-389.

Whiteley, H. R. \& Douglas, H. C. (1951). The fermentation of purines by Micrococcus lactilyticus. Journal of Bacteriology 61, 605-616.

Wood, W. A. (1961). Fermentation of carbohydrates and related compounds. In The Bacteria, vol. 2, pp. 59-150. Edited by I. C. Gunsalus \& R. Y. Stanier. New York: Academic Press.

Wright, D. E. \& Hungate, R. E. (1967). Metabolism of glycine by rumen microorganisms. Applied Microbiology 15, 152-157. 